\title{
SCHOOL LEADERSHIP, PERSONALITY, DAN MOTIVASI, TERHADAP PROFESIONALISME GURU SEKOLAH DASAR
}

\author{
Nurhayati \\ Mahasiswa S2 Pendidikan Dasar Universitas Negeri Jakarta \\ nurhayatialifah@yahoo.com
}

\begin{abstract}
The study aims to determine the impact of school leadership, personality, and motivation in the professionalism of teachers of State Primary School. Data analysis technique used is path analysis. Data population was selected by random sampling, from 10 groups selected one group, about 82 teachers. Data was obtained by questionnaire which has been tested. In conclusion, professionalism of teacher in state primary schools, has a variety of characteristics, professionalism of teachers influenced either by several variables, including the school leadership, personality, and motivation. The implication is that the professionalism of teachers will increase if there is, good school leadership, good personality of a teacher, and high teacher motivation.
\end{abstract}

Keyword : school leadership, personality, motivasion

\begin{abstract}
Abstrak : Penelitian bertujuan untuk mengetahui pengaruh school leadershif, personality, dan motivasi terhadap profesionalisme guru Sekolah Dasar. Teknik analisis data yang digunakan adalah analisis jalur. Populasi data dipilih secara Random Sampling, dari 10 gugus terpilih satu gugus, sebanyak 82 guru. Data diperoleh dengan angket yang telah diuji coba. Kesimpulannya, profesionalisme guru Sekolah Dasar, memiliki keragaman karakteristik, profesionalisme guru dipengaruhi oleh beberapa variabel, diantaranya, school leadership, kepribadian personality, dan motivasi. Implikasinya bahwa profesionalisme guru akan semakin meningkat apabila terdapat school leadership yang baik, personality guru yang baik, dan motivasi guru yang tinggi.
\end{abstract}

Kata kunci : profesionalisme guru, school leadership, personality, motivasi

Pendidikan di Indonesia adalah seluruh mengikuti program wajib belajar pendidikan yang diselenggarakan di pendidikan dasar selama sembilan tahun, Indonesia, baik itu secara terstruktur enam tahun di sekolah dasar/madrasah maupun tidak terstruktur. Secara ibtidaiyah dan tiga tahun di sekolah terstruktur, pendidikan di Indonesia menengah pertama/madrasah tsanawiyah. menjadi tanggung jawab Kementerian Saat ini, pendidikan di Indonesia diatur Pendidikan dan Kebudayaan Republik melalui Undang-Undang Nomor 20 Tahun Indonesia (Kemdikbud), dahulu bernama 2003 tentang Sistem Pendidikan Departemen Pendidikan Nasional Nasional.Pendidikan di Indonesia terbagi Republik Indonesia (Depdiknas). Di ke dalam tiga jalur utama, yaitu formal, Indonesia, semua penduduk wajib nonformal, dan informal. Pendidikan juga 
School Leadership, Personality, Dan Motivasi, Terhadap Profesionalisme Guru Sekolah Dasar Nurhayati

dibagi ke dalam empat jenjang, yaitu anak usia dini, dasar, menengah, dan tinggiPendidikan yang diharapkan Bangsa Indonesia adalah pendidikan yang dapat menghasilkan lulusan berupa sumber daya manusia yang kreatif, inovatif, berkepribadian dan berkarakter baik, bukan hanya lulusan yang pintar dan tinggi nilai akademisnya saja.

Berdasarkan data dari Education For All (EFA) Global Monitoring Report 2011 (UNESCO: 2011) indeks pembangunan pendidikan atau Education Development Index (EDI) nilai Indonesia ber-dasarkan data tahun 2008 adalah 0,934.Nilai tersebut menempatkan Indonesia di posisi ke-69 dari 127 negara.

Laporan Pembangunan Manusia 2014 berjudul "Mem-pertahankan Kemajuan Manusia: Mengurangi Kerentanan dan Membangun Ketahanan", dirilis (24/7) oleh United Nations Development Programme (UNDP: 2017). Dengan menggunakan Indeks Pembangunan Manusia (IPM), yaitu kombinasi dari indikator-indikator seperti kesehatan, kekayaan dan pendidikan, peringkat Indonesia berada pada posisi 108 dari 187
Data tersebut menunjukan bahwa pendidikan di Indonesia belum mampu menciptakan sumber daya manusia (SDM) yang ber-kualitas. Peringkat Indonesia yang berada jauh dibawah Singapura, Brunei Darusalam, Malaysia, dan Thailand, seharusnya menjadi cambuk bagi para pelaksana pendidikan dan pemangku kebijakan dunia pendidikan, untuk terus memacu semangat dan motivasinya, agar dapat meningkatkan profesionalismenya.

Belajar sebagai suatu proses berfokus pada apa yang terjadi ketika belajar berlangsung. Penjelasan tentang apa yang terjadi merupakan teori-teori belajar.Teori belajar adalah upaya untuk menggambarkan bagaimana orang dan hewan belajar, sehingga membantu kita memahami proses kompleks inheren pembelajaran.

Ada tiga kategori utama atau kerangka filosofis mengenaiteori belajar, yaitu: behaviorisme, kognitivisme, dan konstruktivisme. Behaviorisme hanya berfokus pada aspek objektif diamati pembelajaran.Teori kognitif melihat melampaui perilaku untuk menjelaskan pembelajaran berbasis otak. Dan pandangan konstruktivisme belajar sebagai 
JURNAL PENDIDIKAN DASAR

Volume 6 Edisi 1 mei 2017

sebuah proses di mana pelajar aktif membangun atau membangun ide-ide baru atau konsep

Berdasarkan hasil observasi dan wawancara peneliti dengan staf Dinas Pendidikan Pemuda dan Olahraga Kabupaten Purwakarta, peneliti memperoleh informasi data prestasi siswa dan guru pada tahun pelajaran 2012 2015 Prestasi guru sekolah dasar di Kabupaten Purwakarta baik Guru Berprestasi, maupun Olimpiade Sains Guru, belum mendapatkan prestasi puncak. Profesionalisme guru dapat tergambar dalam perolehan nilai $\mathrm{UKG}$ di Purwakarta yang masih rendah, nilai UKG 2013 tertinggi 73 , terendah 0 dan rata-rata 32. Tidak jauh beda dengan perolehan nilai UKG SD di Jawa Barat tertinggi 77,00 , terendah 0,00 dan rata-rata 42,81 . Berdasarkan data kemdikbud tahun 2013, nilai UKG secara nasional, dari 164.539 peserta diperoleh nilai tertinggi 96,25 terendah 0,0 dan rata-rata 45,82 dengan standar deviasi 9,27. UKG menguji kompetensi pedagogik, dan profesionalisme. Sedangkan hasil perolehan nilai Ujian Sekolah SD/MI di Purwakarta, (Disdikpora Purwakarta: 2015) tahun pelajaran 2014 - 2015 tertinggi 275,32 terendah 153,18 dalam

rentang puluhan dengan mata uji tiga mata pelajaran.

Penyebab kegagalan tersebut adalah kurangnya kualifikasi guru yang dinilai belum optimal. Oleh karena itu masalah profesionalisme guru menjadi isu utama dalam penyelenggaraan pendidikan di Purwakarta, khusus-nya pada jenjang pendidikan sekolah dasar.

Pada studi pendahuluan yang telah dilakukan, Peneliti me-wawancarai guruguru SD dan menemukan beberapa masalah, yang berdampak pada profesionalis-me guru, antara lain: (1) Kurang relevannya latar belakang pendidik-an guru dengan tugas mengajarnya, (2) Masalah kepemimpinan kepala sekolah, tidak jarang menimbulkan konflik dengan guru akibat ketidakpuasan terhadap kebijakan, gaya kepemimpinan maupun masalah keadilan. (3) Pemberian penghargaan pada guru kurang. Keberhasilan seorang guru baik secara pribadi maupun keberhasilan dalam bentuk prestasi siswa, sering kali tidak dianggap sebagai keberhasilan profesionalisme guru tetapi lebih condong sebagai hal yang sewajarnya, sehingga mem-pengaruhi motivasi untuk mencapai yang lebih baik. (4) Kurangnya motivasi kerja guru, menyebabkan aktivitas pembelajaran yang dikelola guru tak ubahnya sebagai suatu 
School Leadership, Personality, Dan Motivasi, Terhadap Profesionalisme Guru Sekolah Dasar Nurhayati

proses kerja rutin tanpa upaya pencapaian prestasi. (5) Per-masalahan jenjang karir, guru untuk menduduki jabatan pimpinan (kepala sekolah) tidak hanya ditentukan oleh prestasi kerjanya tetapi faktor-faktor subjektifitas, dan keterlibatan pejabat dinas pendidikan, (6) Masih banyak guru yang sudah tersertifikasi tapi belum mampu mendesain perangkat pembelajaran, merencanakan pembelajaran, mengevaluasi pembelajar-an, dan menunjukkan ke-profesionalannya dengan baik. (7) Dalam pengelolaan dan peng-embangan proses pembelajaran masih ada guru menjadi miskin kreatifitas, karena selalu terikat dengan berbagai aturan yang kaku, terlebih dengan adanya kewajiban untuk mencapai target materi kurikulum, dan pembuatan berbagai perangkat administrasi yang bermacammacam,(8) Masih ditemukan guru yang kurang disiplin dalam melaksanakan tugas, seperti datang terlambat ke sekolah, atau mengulur-ngulur waktu untuk masuk kelas. (9) Pembinaan terhadap guru khususnya dalam pengembangan diri sebagai upaya peningkatan kompetensi masih belum menjadi perhatian para pengambil kebijakan. Kegiatan pendidikan dan latihan, workshop, KKG, seminar, masih jarang dilaksanakan dan belum sepenuhnya berjalan dengan baik (10) Pengembangan diri guru kurang mendapat dukungan, Badan Kepegawaian Daerah (BKD) sulit untuk memberikan izin belajar kepada guru yang melanjutkan pendidikan ke jenjang S2 atau S3. Hal ini berdampak pada ber-kurangnya motivasi guru untuk melanjutkan pendidikan ke jenjang yang lebih tinggi.

Profesionalisme guru berpengaruh besar pada kemajuan pendidikan. Terlepas dari per-masalahan yang ada, seorang guru atau tenaga pendidik harus selalu mengembangkan sikap dan profesionalismenya.Profesionalisme guru dapat efektif terhadap pencapaian tujuan sekolah, karena didukung oleh beberapa faktor, seperti kepemimpinan sekolah, kepribadian guru, motivasi guru, siswa itu sendiri, dan lembaga terkait. Dalam Kemdikbud, (2005:1) UU. No. 14 Tahun 2005 tentang Guru dan Dosen (Pasal 1 ayat 1 ) dijelaskan bahwa:

Guru adalah pendidik professional dengan tugas utama mendidik, mengajar,membimbing, mengarahkan, melatih, menilai dan mengevaluasi peserta didik pada anak usia dini, jalur 
JURNAL PENDIDIKAN DASAR

Volume 6 Edisi 1 mei 2017

pendidikan formal pendidikan dasar dan

strategis dalam mencapai tujuan

pendidikan menengah.

Profesionalisme dan kehadiran guru pendidikan. Menurut Mulyasa,(2011,98) sangat berpengaruh dalam mewujudkan program pendidikan nasional. Guru sebagai pendidik dan pengajar, dituntut untuk menjalankan tugas dan tanggung jawabnya dengan baik. Landasan guru dalam menjalankan tugas sepantasnya bukan hanya tuntutan dari tugas dan tanggungjawabnya saja melainkan keinginan dan motivasi diri yang tinggi untuk memajukan pendidikan dengan kesadaran serta kesukarela-an.

Motivasi seorang guru dengan guru yang lainnya tidak sama, sehingga menghasilkan profesionalisme yang berbeda pula. Oleh karena itu agar motivasi guru mengarah pada hal-hal yang positif perlu adanya sentuhan dari kepala sekolah sebagai atasan langsung, dan peningkatan kualitas ke-pribadiannya.

Tercapainya tujuan pendidik-an di tingkat satuan pendidikan juga tidak lepas dari kualitas ke-pemimpinan sekolah (school leadership). Kepemimpinan kepala sekolah dan kepribadian guru berpengaruh pada tumbuhnya motivasi baik motivasi berperilaku profesional, maupun motivasi berkembang dan motivasi ber-prestasi pada diri guru. Dalam pendidikan modern kepala sekolah merupakan jabatan

kepala sekolah sedikitnya mempunyai peran dan fungsi sebagai Educator, Manajer, Administrator, Supervisor, Leader, Inovator dan Motivator (EMASLIM), diharapkan dengan pelaksanaan semua peran tersebut memberi dampak positif bagi guru dan peserta didik yang berimbas pada tercapainya tujuan pendidikan nasional

Kepemimpinan sekolah (School leadership) merupakan indikator penting dalam mewujudkan tujuan pendidikan. Kepala sekolah sebagai pemimpin mempunyai peranan strategis, sebagai seorang manajer, dia dapat membuat atau menciptakan suasana sekolah yang kondusif dan refresentatif bagi guru dan tenaga kependidikan untuk giat bekerja menjalankan tugas dan tanggung jawabnya di sekolah, serta giat mengembangkan diri. Kepala sekolah sebagai manajer menempati posisi yang ditentukan dalam organisasi sekolah, memegang kunci keberhasilan dalam mencapai tujuan yang telah ditentukan, hal ini menunjukkan bahwa kepala sekolah sebagai pemegang jasa profesional yang sangat khusus.

Rohiyat, (2010:35) mengemukakan, keterampilan manajerial kepala sekolah perlu mendapat perhatian seperti 
School Leadership, Personality, Dan Motivasi, Terhadap Profesionalisme Guru Sekolah Dasar Nurhayati

pemahaman tentang tugasnya untuk memanejemen kurikulum, me-manajemen personil, fasilitas, keuangan dan tata usaha sekolah, pemeliharaan tata tertib, dan penghubung sekolah-masyarakat. Aspek lainnya yang perlu di-perhatikan adalah keterampilan dalam menyusun rencana, mengambil keputusan, memeriksa dan menilai hasil-hasil, menyampaikan instruksi memecahkan konflik yang muncul, memupuk semangat bekerja dan memotivasi. Begitu besar peran kepemimpinan sekolah sehingga rasa kekeluargaan juga harus dibangun untuk menciptakan kerjasama tim yang solid dalam mencapai tujuan. Menurut Sallis, (2010:171) tanpa kepemimpinan pada suatu institusi, proses peningkatan mutu tidak dapat dilakukan dan diwujudkan, karena Total Quality Management (TQM) adalah proses atas ke bawah (top-down).

Kepribadian seorang guru juga mempengaruhi motivasinya, tidak jarang ditemukan seorang guru yang tidak memiliki motivasi tinggi, meskipun kepemimpinan sekolahnya sudah bagus. Sebaliknya ada pula guru yang tetap memiliki motivasi tinggi meskipun kepemimpinan sekolahnya kurang ideal. Menurut Hall \& lindzey, (1999:26),
"Kepribadian merupakan keterampil-an kecakapan sosial. Kepribadian individu dinilai berdasarkan kemampuannya memperoleh reaksi-reaksi positif dari berbagai orang dalam berbagai keadaan." Seseorang ada yang berkepribadian agresif, penurut, penakut, pemalu, atau pemalas. Kepribadian akan tergambar dari pola tingkah laku sehari-hari, pekerjaan yang diemban akan terpengaruh oleh kepribadian-nya. Pemimpin yang baik harus bisa memberikan dorongan yang sesuai dengan kepribadian guru, sehingga tujuan meningkatkan motivasi kerja guru dapat tercapai dan berpengaruh positif kepada profesionalismenya.

Dari fenomena di atas, peneliti tertarik melakukan penelitian tentang "Pengaruh Kepemimpinan Sekolah (School leadership), Personality, dan Motivasi Terhadap Profesionalisme Guru Sekolah Dasar di Kabupaten Purwakarta”. Penelitian ini perlu dilakukan mengingat kecenderungan ke-pemimpinan sekolah, kepribadian, dan motivasi sangat penting demi peningkatan profesionalisme guru.

Diidentifikasikan sejumlah permasalahan penelitian, yaitu sebagai berikut: (1) Kepemimpinan sekolah (School Leadership) kurang memberikan 
pembinaan, pengembangan bagi guru.

Sehingga profesionalisme guru rendah,

(2) Kepribadian guru meliputi sifat, sikap, dan watak, ditemukan guru yang pasif, tidak berinovasi, sehingga mempengaruhi rendahnya profesionalisme guru, (3) Kepemimpinan sekolah (School Leadership) selama ini kurang efektif, sehingga guru kurang termotivasi dalam bekerja, kurang disiplin, hal ini berdampak pada kurangnya profesionalisme guru, (4) Kepemimpinan sekolah (School Leadership) selama ini kurang peduli terhadap keberadaan guru, keluhan, serta kesulitan guru, bahkan prestasi guru. Sehingga guru merasa tidak diperhatikan, diabaikan, dan berdampak pada rendahnya motivasi guru, (5) Kepribadian guru yang meliputi sifat, watak, yang terwujudkan pada sikap guru dalam menghadapi perubahan kebijakan dan aturan dalam dunia pendidikan, masih ditemukan guru yang tidak memiliki lima dimensi kepribadian yaitu: openness to experience, conscientiousness, extraversion, emotional stability, dan agreeableness, berakibat pada ketakutan dan keengganan dalam menerima perubahan, sehingga terjadi penurunan motivasi guru, (6) Keanekaragaman kepribadian guru, masih belum mendapat perhatian kepala sekolah, pemahaman watak guru, dan kepedulian akan kebutuhan guru seperti kebutuhan pengembangan profesionalitas guru tidak difasilitasi. Sehingga guru merasa terabaikan dan berakibat pada penurunan motivasi guru.

\section{METODE PENELITIAN}

Metode yang digunakan dalam penelitian kuantitatif yaitu metode survey dengan teknik analisis jalur (path analysis), yaitu penelitian yang berkaitan dengan pengumpulan data untuk menentukan ada atau tidaknya pengaruh antara variable dan seberapa tingkat pengaruhnya. Variabel-variabel penelitian ini adalah: Kepemimpinan Sekolah $\left(\mathrm{X}_{1}\right)$, kepribadian $\left(\mathrm{X}_{2}\right)$, motivasi $\left(\mathrm{X}_{3}\right)$, dan profesionalisme $\left(\mathrm{X}_{1}\right)$, kepribadian $\left(\mathrm{X}_{2}\right)$, motivasi $\left(\mathrm{X}_{3}\right)$.

Populasi target seluruh guru SD negeri di wilayah Kabupaten Purwakarta. Populasi terjangkau seluruh guru SD Negeri di wilayah Purwakarta. Sampel diambil secara random sample yaitu sebanyak 82 guru PNS dari 10 sekolah di gugus 7 pada wilayah kecamatan Purwakarta, dan untuk uji coba instrumen penelitian sebanyak 30 guru.Teknik pengumpulan data yang digunakan dalam penelitian ini adalah angket Instrument

Pengujian persyaratan normalitas dilakukan dengan menggunakan teknik uji 
School Leadership, Personality, Dan Motivasi, Terhadap Profesionalisme Guru Sekolah Dasar Nurhayati

Liliefors. Kriteria pengujian tolak $\mathrm{H}_{0}$ yang menyatakan bahwa skor tidak berdistribusi normal adalah, jika Lhitung lebih kecil dibandingkan dengan $\mathrm{L}_{\text {tabel. }}$ Dari hasil penelitian dapat diketahui bahwa $\operatorname{IF}\left(Z_{i}\right)-$ $\mathrm{S}\left(\mathrm{Z}_{\mathrm{i}}\right) \mathrm{I}$ maksimum yang disimpulkan dengan $\mathrm{L}_{\text {hitung }}$ untuk keenam galat taksiran regresi lebih kecil dari nilai $\mathrm{L}_{\text {tabel, }}$ batas penolakan $\mathrm{H}_{0}$ yang tertera pada tabel Liliefors pada $\alpha=0,05$ dan $\mathrm{n}>30$ adalah. Dari hasil perhitungan uji normalitas diperoleh hasil. bahwa semua hipotesis nol $\left(\mathrm{H}_{0}\right)$ yang berbunyi sampel berasal dari populasi berdistribusi normal tidak dapat ditolak, dengan kata lain bahwa semua sampel yang terpilih berasal dari populasi yang berdistribusi normal. Demikian juga dengan keseluruhan hasil uji signifikansi dan linearitas regresi, hasilnya semua hipotesis dinyatakan signifikan dan linear

\section{HASIL}

Berdasarkan tinjauan pustaka yang telah dibahas dan kajian empiris di atas, berikut dibahas hasil penelitian sebagai upaya untuk melakukan sintesis antara kajian teori dengan temuan empiris.

\section{PEMBAHASAN}

Adapun secara rinci pembahasan hasil analisis dan pengujian hipotesis penelitian diuraikan sebagai berikut:

\section{Pengaruh Kepemimpinan terhadap Profesionalisme}

Dari hasil pengujian hipotesis pertama dapat disimpulkan bahwa terdapat pengaruh langsung positif kepemimpinan terhadap pro-fesionalisme dengan nilai koefisien korelasi sebesar 0,371 dan nilai koefisien jalur sebesar 0,241. Hasil penelitian ini senada dengan pendapat beberapa ahli di antaranya adalah Unsurunsur kepemimpinan dijelaskan oleh Triantoro (2004:4) kepemimpinan melibatkan pengaruh yang besar dalam mewujudkan perubahan yang signifikan, dan perubahan tersebut mencerminkan tujuan yang dimiliki bersama oleh pemimpin dan pengikutnya. Banyak hal yang berpengaruh pada peningkatan profesionalisme seorang guru yaitu, internal adalah faktor dalam diri individu, berupa kepribadiannya, dan kemampuannya, sedangkan faktor internal yaitu lingkungan, bisa berupa, pimpinan, rekan kerja, nasib baik dan jenis kesulitan pekerjaan. Faktor lain yang mempengaruhi profesionalisme guru adalah iklim kerja yang kondusif, sementara itu iklim kerja sangat 
JURNAL PENDIDIKAN DASAR

Volume 6 Edisi 1 mei 2017

ditentukan oleh kepemimpinan kepala sekolah.

Kepemimpinan kepala sekolah yang benar dan

baik akan menciptakan iklim kerja yang kondusif untuk mendukung pelaksanaan tugas dan kewajiban bawahannya, khususnya para guru sebagai tenaga pendidik profesional.

\section{Pengaruh Kepribadian terhadap Profesionalisme}

Dari hasil pengujian hipotesis kedua dapat disimpukan bahwa terdapat pengaruh langsung positif kepribadian terhadap pro-fesionalisme dengan nilai koefisien korelasi sebesar 0,401 dan nilai koefisien jalur sebesar 0,277. Senada dengan pendapat beberapa ahli di antaranya adalahHughes, (2012: 7) kepribadian memiliki dua pengertian yang berbeda. Pertama, arti kepribadian yang mengacu pada kesan seseorang pada orang lain. Pandangan ini menekankan reputasi sosial seseorang dan tidak hanya mencerminkan deskripsi tetapi juga evaluasi seseorang dari sudut pandang orang lain, Kedua, arti kepribadian menekankan struktur tak terlihat dan proses yang mendasari di dalam diri seseorang yang menjelaskan alasan kita berprilaku seperti yang kita lakukan. Salah satunya Freud dalam Alwisol (2014:15) percaya bahwa ketegangan intrapsikis antara id, ego, dan superego menyebabkan seseorang berperilaku dengan karakteristik tertentu. Menurut Kreitner (2008: 133), Kepribadian didefinisikan sebagai kombinasi dari karakteristik fisik dan mental yang stabil yang memberikan identitas individu. The big five personality dimension yang dimiliki seorang individu ini memberikan kontribusi dalam bertindak dan berprilaku. Seorang pegawai dalam melaksanakan tugas dan tanggung jawabnya secara langsung atau pun tidak, akan dipengaruhi oleh kepribadiannya.

Guru sebagai tenaga kependidikan di sekolah agar mampu meningkatkan profesionalis-menya, perlu mendapat pengelola-an, pembinaan, dan pengarahan. Peraturan menteri nomor 23 tahun 2005 tentang standar isi dan standar kelulusan, dilahirkan untuk memperbaiki mutu pendidikan.

Profesionalisme menggambarkan selalu berfikir, berpendirian, bersikap, bekerja dengan sungguh-sungguh, kerja keras, bekerja sepenuh waktu, disiplin, jujur, loyalitas tinggi dan penuh dedikasi untuk keberhasilan pekerjaannya.

Guru adalah salah satu unsur manusia dalam proses pendidikan. Dalam proses pendidikan di sekolah, guru memegang tugas ganda yaitu sebagai pengajar dan pendidik. Sebagai pengajar guru bertugas menuangkan sejumlah bahan pelajaran ke dalam otak anak didik, 
School Leadership, Personality, Dan Motivasi, Terhadap Profesionalisme Guru Sekolah Dasar Nurhayati

sedangkan sebagai pendidik guru bertugas membimbing dan membina anak didik agar menjadi manusia susila yang cakap, aktif, kreatif, dan mandiri.

Hal yang di lakukan guru yaitu mengajar maupun mendidik merupakan tugas dan tanggung jawab guru sebagai tenaga profesional agar menjadi manusia susila yang cakap, aktif, kreatif, dan mandiri. kegiatan mengajar maupun mendidik merupakan tugas dan tanggung jawab guru sebagai tenaga profesional. Oleh sebab itu, tugas yang berat dari seorang guru ini pada dasarnya hanya dapat dilaksanakan oleh guru yang memiliki kompetensi profesional yang tinggi.

Guru memegang peranan sentral dalam proses belajar mengajar, untuk itu mutu pendidikan di suatu sekolah sangat ditentukan oleh kemampuan yang dimiliki seorang guru dalam menjalankan tugasnya. guru adalah faktor penentu bagi keberhasilan pendidikan di sekolah, karena guru merupakan sentral serta sumber kegiatan belajar mengajar.

Hal ini menunjukkan bahwa kemampuan atau kompetensi profesional dari seorang guru sangat menentukan mutu pendidikan. Kompetensi profesional guru dalam hal ini. Berdasarkan hasil Tes Kompetensi Guru yang dilakukan Depertemen Pendidikan Nasional Direktorat Jenderal Pendidikan Dasar dan Menengah Direktorat Pendidikan Lanjutran Pertama yang bekerja sama dengan Pusat Penilaian Pendidikan pada Tahun 2003, menunjukkan bahwa rata-rata nilai kompetensi guru matematika di Kabupaten Pandeglang hanya mencapai $42,25 \%$. Angka ini masih relatif jauh di bawah standar nilai kompetensi minimal yang diharapkan yaitu $75 \%$ nilai kompetensi minimal yang diharapkan yaitu $75 \%$.

\section{Pengaruh Motivasi terhadap} Profesionalisme

Dari hasil pengujian hipotesis ketiga dapat disimpulkan bahwa terdapat pengaruh langsung positif motivasi terhadap profesionalisme dengan nilai koefisien korelasi sebesar 0,391 dan nilai koefisien jalur sebesar 0,243. Ini memberikan makna motivasi berpengaruh langsung terhadap profesionalisme.

Mangkunegara

mengartikan bahwa motif merupakan suatu dorongan kebutuhan dalam diri pegawai yang perlu dipenuhi agar pegawai tersebut dapat menyesuaikan diiri terhadap 
JURNAL PENDIDIKAN DASAR

Volume 6 Edisi 1 mei 2017

lingkungannya, sedangkan motivasi adalah kondisi yang menggerakan pegawai agar mampu mencapai tujuan dari motifnya. Berarti motivasi adalah suatu keadaan seorang pegawai yang menggerakan dirinya untuk bertindak dan berprilaku agar tercapai tujuannya. Colquitt, et al.(2011:179) menyatakan, "Motivation is defined as a set of energetic forces that originates both within and outside an employee, initiates work-related effort, and determinesits direction, intensity, and persistence". Motivasi sebagai seperangkat kekuatan energik yang berasal baik di dalam dan di luar diri, yang menunjukkan usaha yang berhubungan dengan pekerjaan, dan menentukan arah, intensitas, dan ketekunannya.Sependapat dengan Rival (2013: 837) yang mengatakan, motivasi serangkaian sikap dan nilai-nilai yang mempengaruhi individu untuk mencapai hal yang spesifik sesuai dengan tujuan individu." Sikap dan nilai tersebut memberi kekuatan untuk mendorong individu bertingkah laku dalam mencapai tujuan. Motivasi dapat timbul karena keinginan sendiri bisa juga karena faktor dorongan dari luar diri, karena itulah motivasi guru dapat bangkit apabila guru mendapat rangsangan.

Colquit (2011 : 202) menyata-kan bahwa, "Motivation has a strong positive affect on job performance”. Dapat diambil kesimpulan bahwa motivasi yang dimiliki seorang guru memberi pengaruh terhadap profesionalismenya.

\section{Pengaruh Kepemimpinan terhadap Motivasi}

Dari hasil pengujian hipotesis keempat dapat disimpulkan bahwa terdapat pengaruh langsung positif kepemimpinan terhadap motivasi dengan nilai koefisien korelasi sebesar 0,282 dan nilai koefisien jalur sebesar 0,229.

Hughes (2013:7) ber-pendapat bahwa, "Kepemimpinan melibatkan sisi rasional dan emosional dalam pengalaman hidup manusia. Kepemimpinan meliputi sejumlah tindakan dan pengaruh yang didasari oleh alasan dan logika serta inspirasi dan panggilan jiwa". Setiap orang memiliki pikiran, perasaan, harapan, mimpi, kebutuhan, ketakutan, tujuan, ambisi, kekuatan, dan kelemahan yang berbeda-beda, sehingga situasi kepemimpinan menjadi sangat kompleks, pemimpin dapat menggunakan teknik rasional dan daya tarik emosional untuk mempengaruhi pengikutnya, tapi harus menimbang konsekwensi logis dan emosional yang dapat timbul dari tindakan-tindakan mereka sendiri.

Kepemimpinan sekolah dengan skor tinggi dapat menginspirasi dan memotivasi 
School Leadership, Personality, Dan Motivasi, Terhadap Profesionalisme Guru Sekolah Dasar

Nurhayati

pengikut untuk mencapai hasil yang lebih besar dari yang direncanakan dan untuk memperoleh imbalan, untuk berprestasi serta meng-aktualisasikan diri, mampu meng-ekspresikan visi yang jelas dan dapat menjadi inspirasi anggota lainnya untuk berusaha mencapai visi atau tujuan. Kepala sekolah harus dapat membangkitkan motivasi guru. Bentuk perhatian pemimpin tersebut memberi dampak berupa dorongan terhadap guru untuk, selalu siap menjalankan tugas dengan baik, tanpa mengeluh, semua dilakukan dengan suka rela

\section{Pengaruh Kepribadian terhadap Motivasi}

Dari hasil pengujian hipotesis kelima dapat disimpulkan bahwa terdapat pengaruh langsung positif kepribadian terhadap motivasidengan nilai koefisien korelasi sebesar 0,288 dan nilai koefisien jalur sebesar 0,237. Luthans (2011:126) berpendapat, "Per-sonality will mean how people affect others and how they understand and view themselves, as well as their pattern of inner and outher measurable trais and the person-situation interaction". Menurutnya kepribadian adalah bagaimana orang mempengaruhi orang lain dan bagaimana mereka memahami dan melihat dirinya ,serta bagaimana pola ukur karakter dalam dan karakter luar mereka mengukur sifat terukur dalam dan luar serta interaksi antar manusia dan situasi. Menurut Kreitner, (2010:133) "Personality is defined as the combination of stable physical and mental characteristic that give the individual his or her identity. These characteristic or traits-including how one looks, thinks, acts, and feels, are the product of interacting genetic and environmental influences." Individu memiliki cara mereka sendiri dalam berpikir dan bertindak, gaya yang unik hanya mereka sendiri yang memiliki atau menjadi kepribadian-nya, sedangkan menurut McShane (2013:37), "Motivation referesents the forces within a person that affect his or her direction, intensity, and persistence of voluntary behavior". Sejalan dengan Schermerhorn (2012:102), "Motivation is defined as forces within the individual that account for the level direction, level and persistence of person's effort expended at work." Motivasi mengacu kepada seorang individu yang menjelaskan arah tingkat, dan ketekunan usaha yang dikeluarkan seseorang di tempat kerja. Berarti motivasi seseorang sangat dipengaruhi 
JURNAL PENDIDIKAN DASAR

Volume 6 Edisi 1 mei 2017

oleh kepribadian orang tersebut, ketekunan seseorang akan menjadi pendorong bagi bseseorang untuk terus termotivasi untuk melakukan tindakan atau sikap.

\section{Pengaruh \\ Kepemimpinan \\ terhadap Kepribadian}

Dari hasil pengujian hipotesis keenam dapat disimpulkan bahwa terdapat pengaruh langsung positif kepemimpinan terhadap kepribadian dengan nilai koefisien korelasi sebesar 0,223 dan nilai koefisien jalur sebesar 0,223. Kepemimpinan merupakan proses mempengaruhi, memotivasi, dan memungkinkan orang lain untuk berkontribusi terhadap efektifitas dan keberhasilan organisasi atau suatu lembaga pada anggota-anggotanya. Seorang pemimpin harus inovatif, fokus, terbuka, mandiri, dan melakukan hal yang benar.

Kreitner/Kinicki (2008:467)

mendefinisikan, "leadership, process whereby an individual influences others to achieve a common goal." Kepemimpinan adalah proses dimana seorang individu mem-pengaruhi orang lain untuk mencapai tujuan bersama. Matsumoto (2010:255) mendefinisikan, setiap orang adalah pribadi yang unik dengan karakteristik yang berbeda, sifat dan pola fikir untuk mengambil tindakan akan berbeda. Pimpinan harus dapat memahami kepribadian guru, dan memberikan pengaruh kepada masing-masing individu itu pada hal yang positif. Kepemimpinan sekolah yang memilki skor tinggi, dan kepribadian dengan lima aspek domain diperoleh skor tinggi, Hal ini menyebabkan motivasi guru dalam berprestasi maupun dalam kinerja akan membaik.

Kepala sekolah yang kharismatik, tegas, berwibawa, disiplin, dan ramah secara langsung dapat mempengaruhi kepribadian pengikutnya. Karakteristik pengikut-nya akan terpengaruh oleh jiwa kepemimpinan yang ditunjukkan kepala sekolah. Contohnya seorang kepala sekolah yang disiplin, akan menerapkan kedisiplinanya di sekolah yang dia pimpin, hal ini berakibat pada semua guru dan tenaga kependidikannya terbawa disiplin, meskipun pada kenyataannya ada karakteristik guru yang tidak disiplin..

\section{Pengaruh tidak langsung kepemimpinan sekolah $\left(\mathrm{X}_{1}\right)$ terhadap profesionalisme $\left(\mathrm{X}_{4}\right)$.}

Diperoleh besaran total pengaruh tidak langsung, kepemimpinan sekolah $\left(\mathrm{X}_{1}\right)$ terhadap profesionalisme $\left(\mathrm{X}_{4}\right)$ melalui motivasi sebesar $7,44 \%$.

Kepemimpinan memiliki pengaruh terhadap profesionalisme melalui motivasi, ini sesuai dengan pendapat Kreitner dan 
School Leadership, Personality, Dan Motivasi, Terhadap Profesionalisme Guru Sekolah Dasar Nurhayati

Kinicki, $(2008,467)$ yang mendefinisikan, "leadership, process whereby an individual influences others to achieve a common goal." Kepemimpinan adalah proses dimana seorang individu mempengaruhi orang lain untuk mencapai tujuan bersama. Apabila kepemimpinan sekolahnya baik, mampu menjadi leader, innovator, evaluator, dan motivator, gurunya akan termotivasi untuk menjadi guru yang lebih baik, lebih kreatif, inovatif, bertanggung jawab. Sehingga bisa dikategorikan profesionalisme gurunya meningkat.

\section{Pengaruh tidak langsung kepribadian guru $\left(\mathrm{X}_{2}\right)$ terhadap profesionalisme $\left(\mathbf{X}_{4}\right)$ motivasi $\left(\mathbf{X}_{3}\right)$}

Diperoleh total pengaruh kepribadian tidak langsung melalui motivasi sebesar $9,26 \%$. Luthans (2013:126) berpendapat, kepribadian seseorang dipengaruhi oleh gen keturunan dari orang tua, lingkungan, hubungan sosial dengan kelompok dan dari budaya sekitar. Jadi kepribadian merupakan produk dari nature dan nurture, kepemimpinan seseorang yang berhasil memotivasi guru, maka akan dapat meningkatkan profesionalisme gurunya peningkatan motivasi guru tersebut.

\section{Pengaruh tidak langsung kepemimpinan sekolah $\left(\mathrm{X}_{1}\right)$ terhadap motivasi}

Dengan demikian total pengaruh tidak langsung, kepemimpinan sekolah $\left(\mathrm{X}_{1}\right)$ terhadap motivasi $\left(\mathrm{X}_{3}\right)$ melalui kepribadian $\left(\mathrm{X}_{2}\right)$ sebesar 6,45\%. Hasil penelitian ini sejalan dengan Kreitner/Kinicki yang mendefinisikan, "leadership, process whereby an individual influences others to achieve a common goal." Kepemimpinan adalah proses dimana seorang individu mempengaruhi orang lain untuk mencapai tujuan bersama. Pendapat ini sejalan dengan yang disampaikan oleh Schermerhorn, (2012:292) juga berpendapat yang sama yaitu, "leadership is the process of influencing others and the process of facialitating individual and collective efforts to accomplish shared objectives." Kepemimpinan adalah proses mempengaruhi orang lain dan proses memfasilitasi upaya individu dan kolektif untuk mencapai tujuan. Dalam hal ini Kepribadian dipengaruhi faktor gen dan lingkungan sosial. Kepemimpinan sekolah yang memilki skor tinggi, dan kepribadian dengan lima aspek domain memperoleh 
JURNAL PENDIDIKAN DASAR

Volume 6 Edisi 1 mei 2017

skor tinggi, dapat menyebabkan motivasi

guru dalam berprestasi maupun dalam

kinerja akan membaik.

\section{SIMPULAN}

Penelitian menggunakan metode analisis deskriptif, penelitian ini selain dapat menjawab masalah yang telah dikemukakan, juga memberikan kesimpulan yaitu, hasil dari penelitian memperlihatkan variasi profesionalisme guru-guru SD Negeri di Purwakarta memiliki keragaman karakteristik, secara nyata profesionalisme guru dipengaruhi oleh beberapa variabel, khususnya, kepemimpinan sekolah (school leadership), kepribadian (personality), dan motivasi. Berarti kepemimpinan kepala sekolah yang baik dengan skor tinggi, kepribadian guru yang baik, dan tingginya motivasi guru baik motivasi kerja, maupun motivasi berprestasi akan meningkatkan profesionalisme guru Sekolah Dasar di Purwakarta.

Dari hasil analisis juga diperolehan penjelasan bahwa model empiris antar veriabel yang ada sesuai dengan bangun, teori terbukti semua. Pengaruh antara variabel yang ada jalurnya terbukti mempunyai nila pengaruh secara signifikan. Baik pengaruh secara langsung maupun secara tidak langsung.

\section{DAFTAR RUJUKAN}

Anwar Prabu Mangkunegara, 2013 Manajemen Sumber Daya Manusia Perusahaan, Bandung: Rosda Karya

Badin Nuur Tanjung, 2014, Pengaruh Kepemimpinan Kepala Sekolah, kompensasi, dan motivasi kerja terhadap Profesionalisme guru, UNJ

Colquit, Jason A. Lepine, and Michael J. Wasson , 2011, organizational behavior, Improving Perfomance and Commutment in the Workplace, New York: McGraw Hill

Dinas Pendidikan Pemuda dan Olah Raga Purwakarta, 2015, Laporan Hasil Ujian Sekolah SD/MI Tahun Pelajaran 2014-2015, Purwakarta, Disdikpora

Freed Luthans, 2011, Organization Behavior, New York : McGrawHill/ Irwin International Edition

Fred Luthans, Jonathan P. Doh, 2011, International Management, New York : McGraw Hill

Ivancevich, Jhon $\mathrm{M}$ Konopaske and Michael T Matteson, 2008, Organization Behavior and Management, Ninth Edition, New 
School Leadership, Personality, Dan Motivasi, Terhadap Profesionalisme Guru Sekolah Dasar Nurhayati

York: McGraw-Hill Companies, Inc

Jest Feist S., 2008, Teories of Personality , Boston:McGraw-Hill Companies, Inc

Veithzal Rivai, Ela jaufani Sagala, 2013 Manajemen sumber daya Manusia untuk Perusahaan, Depok, $\mathrm{Pt}$ Rajagrafindo

Juan Murray, 2014, Asia-Pacific Journal of Teacher Education, Vol. 42, No. 1 , 7-21, http://dx.doi.org/10.1080/1359866 X.2013.870971

Kementrian Pendidikan dan Kebudayaan , 2005, Undang-Undang No. 14 Tahun 2005 tentang Guru dan Dosen, Jakarta : Kemdikbud RI

Kementrian Pendidikan dan Kebudayaan, 2013, Nilai UKG On Line Guru secara Nasional, Jakarta, Kemdikbud

Kreitner dan Kinicki, organization Behavior, New York : McGrawHill.companis

Linda Evans, 2014, Leadership for Professional Development and Learning: Enhacing our Understanding of how Teachers Develop, (Cambridge Journal of
Education, 2014 Vol. 44, No. 2, 179-198)

McShane, 2013, Organizational Behavior, New York: McGraw-Hill Companies

Richard L. Hughes, Robert C. Ginnett, Gordon J. Curphy, 2013, leadership Enchanging the lessons of Experience,alih bahasa,Jakarta:Salemba

Humanika

Syaiful

Sagala, 2013.Kemampuan Profesional Guru dan Teanaga Kependidikan, Bandung; Alpabeta

Schermerhorn.2012.Organizational Behavior. Twelfth Edition, International Student Version

Triantoro Safaria, 2004, Kepemimpinan, Jakarta: Graha Ilmu

Undang-undang Republik Indonesia Nomor 20 Tahun 2003, tentang Sistem Pendidikan Nasional 